\title{
PENGGUNAAN TEKNOLOGI INFORMASI DAN KOMUNIKASI DAN KEBERFUNGSIAN KELUARGA REMAJA LAKI-LAKI DAN PEREMPUAN
}

\author{
Setiasih Siegit \\ Korespondensi: \\ e-mail: setiasih_siegit@yahoo.com
}

Universitas Surabaya, Jl. Raya Kali Rungkut, Kota Surabaya, Jawa Timur 15811, Indonesia

\begin{abstract}
Information and communication technology (ICT) influences human behavior, including adolescent relationship with parents. Besides positive impact, ICT has a negative impact toward family relationships. The aim of research is to examine the use of information and technology of adolescence and their family functioning. Participants of this research were male and female adolescents, aged 12-16 (N=90). Data collection used McMaster Family Assessment Device (FAD). The study showed there exists no significant differences of using ICT between male and female adolescents. All participants used their gadgets for communication (verbal and written) and browsing. There were neither significant differences of family functioning between male and female adolescents. Other related findings were discussed.
\end{abstract} Article history:

Received 26 December 2017

Received in revised form 3 January 2018

Accepted 17 May 2018

Available online 31 October 2018

Keywords:

information and communication technology; family functioning;

adolescents

\begin{abstract}
Abstrak - Teknologi informasi dan komunikasi (Information and Communication Technology; ICT) memengaruhi pola relasi antar individu, termasuk relasi remaja dengan orang tua. Selain manfaat positif, ICT juga mempunyai dampak negatif terhadap relasi individu dengan keluarga. Tujuan penelitian ini untuk mengetahui penggunaan perangkat ICT pada remaja laki-laki dan perempuan serta keberfungsian keluarganya. Partisipan penelitian ini adalah remaja usia 12-16 tahun $(N=90)$ melalui pengambilan data dengan angket McMaster family assesment device (FAD). Hasil menunjukkan tidak terdapat perbedaan yang signifikan pada penggunaan ICT remaja laki-laki dan perempuan. Partisipan remaja laki-laki maupun perempuan menggunakan perangkat ICT untuk berkomunikasi (lisan dan tulisan) dan mencari informasi. Hasil analisis data juga menunjukkan tidak terdapat perbedaan yang signifikan pada keberfungsian keluarga remaja laki-laki dan perempuan yang memanfaatkan ICT. Penemuan lainnya turut didiskusikan.
\end{abstract}

Kata kunci: teknologi informasi dan komunikasi; keberfungsian keluarga; remaja 


\section{PENDAHULUAN}

Perkembangan informasi dan teknologi terjadi sangat cepat, dari munculnya telepon genggam (1990-2000 awal) untuk menelepon dan mengirim pesan singkat, hingga berkembang teknologi dengan sinyal 3G yang memungkinkan individu untuk berkomunikasi secara langsung dengan panggilan video. Saat ini, adanya internet memungkinkan individu terhubung satu dengan yang lain melalui media sosial, aplikasi untuk berkomunikasi, dan lain sebagainya.

Interaksi melalui internet yang meluas secara potensial dapat memunculkan model relasi baru di dunia sosial, termasuk relasi individu dalam keluarga. Remaja cenderung lebih suka menggunakan perangkat Teknologi Informasi dan Komunikasi (Information and Communication Technology; untuk selanjutnya ditulis ICT) dalam berkomunikasi dengan orang tua maupun dalam pergaulan dengan teman-temannya. Menurut Sigman (2010), mayoritas remaja menghabiskan enam jam sehari bersama perangkat ICT mereka. Orang tua yang mempunyai anak usia remaja, perlahanlahan mempercayakan tanggung jawab kepada anaknya, sambil tetap mengawasi dan memberikan kendali kepada anaknya.

Devitt dan Roker (2009) mengungkapkan bahwa remaja usia 11-17 tahun banyak menggunakan telepon genggam untuk bersosialisasi dengan orang tua dan teman. Pola sosialisasi remaja dengan orang tua dan teman ternyata berbeda. Ketika bersosialisasi bersama teman, mereka lebih banyak bercakap-cakap, saling menyapa, menanyakan kabar, dan sebagainya. Sementara ketika bersosialisasi dengan orang tua, mereka hanya membicarakan hal - hal yang spesifik seperti memberitahukan sedang berada di mana, jam berapa akan pulang, dan jarang melakukan percakapan. Dalam hal ini dapat diartikan bahwa isi komunikasi orang tua dengan remaja yang menggunakan telepon genggam lebih bersifat dangkal dibandingkan dengan teman. Fenomena ini sesuai dengan penelitian Aziz (2016) yang menunjukkan bahwa telepon genggam mengurangi nilai sosial, kurang santun dalam berkomunikasi terutama kepada orang yang lebih tua, dan menjadikan remaja (dalam konteks ini murid Sekolah Lanjutan Tingkat Pertama) lebih individualis.

Pada sisi lain, hasil penelitian Devitt dan Roker (2009) menunjukkan bahwa perangkat teknologi informasi dan komunikasi (ICT) dapat membuat orang tua dan anak memiliki rasa aman. Perangkat ICT mempermudah anak untuk dapat mencari orang tuanya atau mencari pertolongan ketika mereka terpisah dari orang tuanya. Sebaliknya, orang tua juga merasa lebih aman karena dapat dengan mudah menanyakan kabar sang anak ketika tidak bersama mereka. Menurut Lanigan (2009), penggunaan telepon seluler memungkinkan anggota keluarga berkoordinasi aktivitas sehari- 
hari mereka secara real time atau langsung. Meskipun tipe teknologi ini dapat menunjang komunikasi dalam keluarga, namun peneliti memberikan catatan bahwa hal ini juga berpotensi untuk mengurangi isi dan konteks komunikasi, seperti terbatasnya komunikasi non verbal dalam komunikasi lisan.

Menurut Carbonell dkk., (dalam Romero-Ruiz dkk., 2017) jangka waktu penggunaan perangkat ICT yang panjang dapat menyebabkan perubahan perilaku anggota keluarga. Data menunjukkan bahwa terjadi peningkatan persentase individu, dari 11 persen menjadi 28 persen yang semakin jauh dengan keluarga atau tidak menghabiskan waktu bersama keluarga. Mauritzson dan Nordmark (dalam Romero-Ruiz dkk., 2017) menyatakan bahwa penurunan waktu bersama keluarga sejalan dengan pertumbuhan jejaring sosial dan pertemanan banyak terjadi di berbagai populasi. Selain itu peningkatan penggunaan internet berhubungan dengan meningkatnya simtom depresi dan kecemasan.

Chandra (2017) menunjukkan bahwa remaja Sekolah Menengah Pertama paling sering berkomunikasi secara tatap muka, baik dengan ayah (57.4\% remaja) maupun ibu (66.9\% remaja). Bagi remaja, fungsi telepon genggam untuk berkomunikasi dengan orang tua mereka terbagi untuk menghubungi orang tua (ayah sebanyak 23.6\% dan ibu 17.6\%) dan chatting atau SMS (ayah 16.9\% dan ibu 15.5\%). Studi tersebut menunjukkan bahwa remaja lebih banyak berkomunikasi secara tatap muka dengan orang tua, namun sebanyak 54.8 persen remaja juga menyatakan bahwa telepon genggam mempunyai pengaruh kuat terhadap cara komunikasi mereka dengan orang tua. Kuatnya pengaruh ini ditunjukkan dengan 28.4 persen remaja menilai pada skor 6 dan 26.4 persen menilai pada skor 7 dari rentang skor 1-7.

Hasil survei awal peneliti pada 22 remaja usia 12-16 tahun di Surabaya menunjukkan bahwa hampir semua partisipan (95.5\%) memiliki telepon genggam. Hasil survei awal peneliti juga menunjukkan bahwa mereka memiliki telepon genggam saat berusia 9 tahun (sebanyak 36.4\%) dan ketika mereka berusia 12 tahun (sebanyak 27.3\%). Partisipan survei awal mengatakan bahwa mereka sering menggunakan perangkat ICT mereka untuk berinteraksi dan berkomunikasi dengan anggota keluarga $(63.6 \%)$ dan 22 persen lainnya mengatakan jarang menggunakan gawai mereka untuk berkomunikasi dengan keluarga. Sebagian besar partisipan, yakni 63.6 persen menyatakan sering berkomunikasi dengan menggunakan perangkat ICT dan hanya 45.5 persen partisipan yang memiliki kelompok berbincang-bincang dalam aplikasi untuk berkomunikasi antar anggota keluarga. Secara umum, mayoritas partisipan survei awal (68\%) menyatakan bahwa dengan teknologi informasi dan komunikasi berdampak baik pada hubungan antar anggota keluarga mereka. 
Komunikasi merupakan cara yang penting untuk menyampaikan suatu pendapat, tercapainya suatu tujuan, pembagian peran, dan lain sebagainya. Perkembangan teknologi baik secara langsung maupun tidak langsung telah mengubah cara berkomunikasi antar anggota keluarga. Perkembangan teknologi menjadikan komunikasi antar individu lebih mudah, cepat, dan murah, tetapi di sisi lain juga menyebabkan berkurangnya kontak fisik (tatap muka) secara langsung. Perubahan cara berkomunikasi dapat menyebabkan perubahan pada keberfungsian suatu keluarga. Fungsi suatu keluarga dapat dikatakan baik apabila terjadi interaksi antara setiap anggota dalam upaya memenuhi kebutuhan dasar, mengambil keputusan, membuat peraturan, hingga mendiskusikan pencapaian tujuan keluarga (Lanigan, 2009).

Menurut McMaster family functioning model, terdapat tujuh aspek keberfungsian keluarga, yaitu pemecahan masalah, komunikasi, peran, respons afektif, keterlibatan afektif, kontrol perilaku, dan fungsi umum keluarga.

Aspek pertama, pemecahan masalah, mengacu pada kemampuan anggota keluarga menyelesaikan masalah dalam keluarga. Suatu keluarga yang berfungsi baik dapat menyelesaikan permasalahan dengan baik, sebaliknya keluarga yang tidak berfungsi baik akan cenderung tidak dapat menyelesaikan atau hanya menyelesaikan sebagian dari masalah yang ada (Epstein, Baldwin, \& Bishop, 1983). Aspek kedua ialah komunikasi, mengacu pada proses pertukaran informasi secara verbal antar anggota keluarga. Aspek ketiga ialah peran, merupakan pola perilaku yang berulang guna memenuhi fungsi keluarga. Terdapat lima peran dasar keluarga yaitu penyedia sumber daya, perawatan dan dukungan, kepuasan seksual individu dewasa, pengembangan pribadi, serta pemeliharaan dan pengelolaan sistem keluarga. Suatu keluarga yang berfungsi dengan baik dapat memenuhi semua peran dalam keluarga, bertanggung jawab, dan dapat berbagi peran dengan baik antar anggota keluarga. Aspek keempat merupakan respons afektif, yakni kemampuan bereaksi terhadap stimulus yang ada dengan kualitas dan kuantitas afeksi yang tepat. Aspek ini lebih mengacu pada kapasitas anggota keluarga untuk merasakan dan mengekspresikan emosi secara tepat. Keluarga yang berfungsi baik mampu mengekspresikan emosi secara baik dan tepat sesuai dengan kondisi yang terjadi. Aspek kelima, keterlibatan afektif, merupakan kemampuan setiap anggota keluarga menunjukkan apresiasi dan rasa tertarik terhadap aktivitas dan minat anggota keluarga lainnya. Aspek keenam ialah kontrol perilaku, menggambarkan cara anggota keluarga dalam menghadapi masalah dengan tiga kondisi, yaitu membahayakan fisik, membutuhkan pemenuhan kebutuhan psikobiologis, dan melibatkan perilaku sosial antar anggota keluarga maupun orang lain. Terdapat empat kategori kontrol perilaku di dalam keluarga, yaitu kaku, fleksibel, laissez-faire atau berubah-ubah, dan tidak beraturan. Pada keluarga yang berfungsi baik, 
kontrol perilaku yang muncul cenderung bersifat fleksibel, sedangkan kontrol perilaku pada keluarga yang tidak berfungsi dengan baik akan cenderung tidak beraturan. Aspek ketujuh, yaitu fungsi umum keluarga, merupakan kondisi kesehatan fisik anggota keluarga, komunikasi, peran, dan lainnya dalam kondisi tertentu.

Keberfungsian keluarga penting dalam menunjang perkembangan baik fisik maupun psikologis remaja. Laghi dkk., (dalam Bonnaire \& Phan, 2017) menyatakan bahwa jenis kelamin remaja berpengaruh pada beberapa dimensi keberfungsian keluarga dan perilaku bermasalah, seperti misalnya disfungsional perilaku makan remaja. Pada usia remaja, seorang anak mulai memiliki pergaulan yang luas dan dapat mengoperasikan telepon genggam mereka secara maksimal. Hasil penelitian Bonnaire dan Phan (2017) menunjukkan bahwa dalam seminggu dan akhir pekan, remaja laki-laki (yang tergolong non problematic gamer/NPG) menggunakan lebih banyak waktunya untuk bermain video daripada remaja perempuan NPG. Terdapat perbedaan pola penggunaan ICT antara laki-laki dan perempuan. Perempuan lebih banyak menggunakan ICT untuk berkomunikasi, sedangkan laki-laki lebih banyak menggunakan ICT untuk bermain online video games dengan waktu lebih lama dan lebih sering. Lenhart dkk., (dalam Carvalho, Francisco, \& Relvas, 2015). Penelitian ini bertujuan untuk mengetahui penggunaan ICT dan keberfungsian keluarga pada remaja laki-laki dan perempuan. Hipotesis penelitian yang diajukan dalam penelitian ini adalah adanya perbedaan keberfungsian keluarga antara remaja laki-laki dan perempuan yang menggunakan ICT.

\section{METODE}

\section{Partisipan}

Partisipan pada penelitian ini adalah remaja yang berusia 12-16 tahun, baik laki-laki maupun perempuan, memiliki dan menggunakan perangkat ICT (gawai) dalam kehidupan sehari-hari. Remaja yang menjadi partisipan penelitian ini adalah remaja yang sedang berada di dua pusat perbelanjaan modern di Surabaya yang secara kebetulan dijumpai oleh peneliti dan bersedia untuk mengisi angket penelitian. 


\section{Desain Penelitian}

Penelitian ini merupakan penelitian non eksperimental dengan mengambil data partisipan melalui survei. Desain penelitian ini bertujuan untuk memberikan informasi tentang penggunaan telepon genggam dan keberfungsian keluarga pada remaja laki-laki dan perempuan.

Data tentang keberfungsian keluarga diperoleh dengan the Mcmaster family assesment device (FAD) dari Epstein dkk., (1983) yang juga digunakan oleh Djabumir (2015). Contoh butir pernyataan untuk mengungkap aspek pemecahan masalah: 'Keluarga saya membuat keputusan sesuai dengan masalah yang ada'. Contoh butir pernyataan untuk mengungkap aspek komunikasi: 'Saya langsung mengatakan sesuatu yang ingin dibicarakan dalam keluarga dan tidak menggunakan isyarat tertentu'. Contoh butir pernyataan untuk mengungkap aspek peran: 'Kami mendiskusikan siapa saja yang mengerjakan pekerjaan rumah'. Contoh butir pernyataan untuk mengungkap aspek respons afektif: 'Setiap anggota keluarga mengekspresikan kasih sayang mereka'. Contoh butir pernyataan untuk mengungkap aspek keterlibatan afektif: 'Apabila ada anggota keluarga yang mengalami kesulitan, anggota keluarga lainnya membantu'. Contoh butir pernyataan untuk mengungkap aspek kontrol perilaku: 'Setiap anggota keluarga tahu yang harus dilakukan dalam keadaan darurat'. Contoh butir pernyataan untuk mengungkap aspek fungsi umum keluarga: 'Setiap anggota keluarga diterima apa adanya'.

Hasil uji reliabilitas pada penelitian ini menunjukkan Cronbach Alpha sebesar .921. Data tentang penggunaan teknologi informasi dan komunikasi, serta data demografis partisipan yang diperoleh melalui angket.

\section{Prosedur}

Pengambilan data penelitian ini dilakukan selama tiga hari, yaitu tanggal 22, 23, dan 26 Desember 2016. Pada proses pengambilan data ini terlebih dahulu peneliti menyapa dan meminta kesediaan untuk mengisi angket penelitian kepada remaja yang dijumpai di pusat perbelanjaan. Jika remaja tersebut bersedia, maka sebelumnya diminta untuk mengisi lembar kesediaan, selanjutnya mengisi angket penelitian.

Pada tanggal 22 Desember 2016 dilakukan pengambilan data di pusat perbelanjaan A, jumlah partisipan yang diperoleh 44 partisipan. Pada tanggal 23 Desember 2016 pengambilan data dilakukan di pusat perbelanjaan B, jumlah partisipan yang diperoleh 10 orang. Pada tanggal 26 Desember 2016 pengambilan data dilakukan di pusat perbelanjaan A lagi, jumlah partisipan yang diperoleh 41 orang. Secara keseluruhan, jumlah angket yang diisi partisipan adalah 95 buah, namun 
jumlah angket yang dapat digunakan untuk analisis lebih lanjut adalah 90 buah, karena terdapat 2 angket yang tidak diisi secara lengkap dan 3 angket tidak sesuai dengan kriteria penelitian.

\section{Teknik Analisis Data}

Data penelitian yang diperoleh diolah atau dianalisis dengan teknik statistik Independent Sample T-Test. Teknik statistik ini digunakan untuk membuktikan ada atau tidaknya perbedaan keberfungsian keluarga antara remaja laki-laki dan remaja perempuan yang menggunakan ICT. Selain itu, untuk memperoleh gambaran tentang penggunaan ICT pada remaja laki-laki dan remaja perempuan digunakan statistik deskriptif dalam bentuk distribusi frekuensi.

\section{ANALISIS DAN HASIL}

Partisipan penelitian ini sejumlah 90 orang, dengan komposisi lebih banyak remaja perempuan $(51.1 \%)$ dibanding remaja laki-laki (48.9\%). Deskripsi lebih rinci dapat dilihat pada tabel 1 .

Tabel 1.

Deskripsi Data Subjek

\begin{tabular}{|c|c|c|c|c|c|c|c|}
\hline \multirow[b]{2}{*}{ Variabel } & & \multicolumn{2}{|c|}{ Laki-laki } & \multicolumn{2}{|c|}{ Perempuan } & \multicolumn{2}{|c|}{ Total } \\
\hline & & $F$ & $\%$ & $F$ & $\%$ & $F$ & $\%$ \\
\hline \multirow{5}{*}{ Usia (tahun) } & 12 & 7 & 15.9 & 7 & 15.2 & 14 & 15.6 \\
\hline & 13 & 6 & 13.6 & 8 & 17.4 & 14 & 15.6 \\
\hline & 14 & 16 & 36.4 & 21 & 45.7 & 37 & 41.1 \\
\hline & 15 & 7 & 15.9 & 8 & 17.4 & 15 & 16.7 \\
\hline & 16 & 8 & 18.2 & 2 & 4.3 & 10 & 11 \\
\hline Total & & 44 & 100 & 46 & 100 & 90 & 100 \\
\hline
\end{tabular}

Hasil penelitian pada tabel 1 menunjukkan bahwa mayoritas partisipan penelitian ini berusia 14 tahun (jumlah remaja laki-laki dan perempuan $=41.1 \%$ ), dengan rincian remaja laki-laki usia 14 tahun sebanyak 36.4 persen dan remaja perempuan usia 14 tahun sebanyak 45.7 persen.

Gambaran rinci tentang penggunaan ICT pada remaja (lihat tabel 2) menunjukkan bahwa surat elektronik merupakan perangkat ICT yang jarang digunakan, baik oleh remaja laki-laki (43.2\%) maupun remaja perempuan (50\%). Sebanyak 50 persen remaja laki-laki sering menggunakan telepon, sedangkan 45.7 persen remaja perempuan kadang-kadang menggunakan telepon. Sebanyak 43.2 persen remaja laki-laki sering menggunakan layanan pesan singkat (SMS), sedangkan 37 persen remaja perempuan kadang-kadang menggunakan SMS. Layanan percakapan 
sering digunakan oleh remaja laki-laki (45.5\%), sedangkan remaja perempuan (50\%) selalu menggunakan ICT untuk bercakap-cakap. Sebanyak 31.8 persen remaja laki-laki jarang menggunakan layanan percakapan video, sedangkan 32.6 persen remaja perempuan kadang-kadang menggunakan layanan percakapan video. Partisipan laki-laki (43.2\%) menggunakan media sosial, sedangkan remaja perempuan $(37 \%)$ hampir selalu menggunakan media sosial. Untuk pencarian informasi, terdapat 29.5 persen remaja laki-laki yang jarang melakukannya dan 29.5 persen yang termasuk sering menggunakannya atau sama banyak. Sementara, remaja perempuan (30.4\%) tergolong sering menggunakan ICT untuk pencarian informasi.

Tabel 2.

Deskripsi Penggunaan ICT

\begin{tabular}{|c|c|c|c|c|c|}
\hline \multirow{2}{*}{\multicolumn{2}{|c|}{ Variabel }} & \multicolumn{2}{|c|}{ Laki-laki } & \multicolumn{2}{|c|}{ Perempuan } \\
\hline & & \multirow{2}{*}{$\begin{array}{l}F \\
7\end{array}$} & \multirow{2}{*}{$\begin{array}{c}\% \\
15.9\end{array}$} & \multirow{2}{*}{$\begin{array}{c}\boldsymbol{F} \\
8\end{array}$} & \multirow{2}{*}{$\begin{array}{c}\% \\
17.4\end{array}$} \\
\hline Penggunaan email (surat & Tidak pernah & & & & \\
\hline elektronik) & Jarang & 19 & 43.2 & 23 & 50 \\
\hline & Kadang-kadang & 10 & 22.7 & 12 & 26.1 \\
\hline & sering & 8 & 18.2 & 3 & 6.5 \\
\hline & Hampir selalu & 0 & 0 & 0 & 0 \\
\hline Total & & 44 & 100 & 46 & 100 \\
\hline \multirow[t]{5}{*}{ Penggunaan telepon } & Tidak pernah & 1 & 2.3 & 1 & 2.2 \\
\hline & Jarang & 10 & 22.7 & 12 & 26.1 \\
\hline & Kadang-kadang & 9 & 20.5 & 21 & 45.7 \\
\hline & sering & 22 & 50 & 8 & 17.4 \\
\hline & Hampir selalu & 2 & 4.5 & 4 & 8.7 \\
\hline Total & & 44 & 100 & 46 & 100 \\
\hline \multirow{5}{*}{$\begin{array}{l}\text { Penggunaan layanan pesan } \\
\text { singkat (SMS) }\end{array}$} & Tidak pernah & 4 & 9.1 & 3 & 6.5 \\
\hline & Jarang & 9 & 20.5 & 16 & 34.8 \\
\hline & Kadang-kadang & 10 & 22.7 & 17 & 37 \\
\hline & sering & 19 & 43.2 & 6 & 13 \\
\hline & Hampir selalu & 2 & 4.5 & 4 & 8.7 \\
\hline Total & & 44 & 100 & 46 & 100 \\
\hline \multirow{5}{*}{$\begin{array}{l}\text { Penggunaan chatting } \\
\text { (layanan percakapan) }\end{array}$} & Tidak pernah & 0 & 0 & 1 & 2.2 \\
\hline & Jarang & 3 & 6.8 & 3 & 6.5 \\
\hline & Kadang-kadang & 7 & 15.9 & 9 & 19.6 \\
\hline & sering & 20 & 45.5 & 10 & 21.7 \\
\hline & Hampir selalu & 14 & 31.8 & 23 & 50 \\
\hline Total & & 44 & 100 & 46 & 100 \\
\hline \multirow{5}{*}{$\begin{array}{l}\text { Penggunaan video call } \\
\text { (layanan percakapan } \\
\text { video) }\end{array}$} & Tidak pernah & 8 & 18.2 & 4 & 8.7 \\
\hline & Jarang & 14 & 31.8 & 13 & 28.3 \\
\hline & Kadang-kadang & 7 & 15.9 & 15 & 32.6 \\
\hline & sering & 11 & 25 & 9 & 19.6 \\
\hline & Hampir selalu & 4 & 9.1 & 5 & 10.9 \\
\hline Total & & 44 & 100 & 46 & 100 \\
\hline \multirow[t]{4}{*}{ Penggunaan social media } & Tidak pernah & 1 & 2.3 & 3 & 6.5 \\
\hline & Jarang & 2 & 4.5 & 3 & 6.5 \\
\hline & Kadang-kadang & 11 & 25 & 13 & 28.3 \\
\hline & sering & 19 & 43.2 & 10 & 21.7 \\
\hline
\end{tabular}




\begin{tabular}{llcccc}
\hline & & \multicolumn{2}{c}{ Laki-laki } & \multicolumn{2}{c}{ Perempuan } \\
\cline { 3 - 6 } & Variabel & $\boldsymbol{F}$ & $\mathbf{\%}$ & $\boldsymbol{F}$ & $\mathbf{\%}$ \\
\hline Total & Hampir selalu & 11 & 25 & 17 & 37 \\
\hline Browsing (pencarian & & 44 & 100 & 46 & 100 \\
informasi) & Tidak pernah & 1 & 2.3 & 3 & 6.5 \\
& Jarang & 13 & 29.5 & 5 & 10.9 \\
& Kadang-kadang & 12 & 27.3 & 12 & 26.1 \\
& sering & 13 & 29.5 & 14 & 30.4 \\
& Hampir selalu & 5 & 11.4 & 12 & 26.1 \\
\hline Total & & 44 & 100 & 46 & 100 \\
\hline
\end{tabular}

Tabel 3 menunjukkan cara berkomunikasi antara remaja dengan orang tuanya, baik ayah maupun ibu. Sebagian besar remaja berkomunikasi secara tatap muka dengan ibunya, baik remaja laki-laki (63.6\%) maupun perempuan (71.7\%). Demikian juga dengan ayah, sebagian besar remaja berkomunikasi secara tatap muka dengan ayahnya, baik remaja laki-laki (50\%) maupun perempuan (63\%). Meskipun sebagian partisipan juga berkomunikasi dengan ayah dan ibunya menggunakan telepon dan layanan pesan singkat atau percakapan, namun jumlah remaja yang berkomunikasi dengan cara ini lebih sedikit dibandingkan dengan tatap muka.

Tabel 3.

Cara Remaja Berkomunikasi Dengan Orang Tua

\begin{tabular}{llcccc}
\hline \multirow{2}{*}{$\begin{array}{l}\text { Komunikasi remaja dengan orang tua lebih } \\
\text { sering melalui: }\end{array}$} & \multicolumn{2}{c}{ Laki-laki } & \multicolumn{2}{c}{ Perempuan } \\
\cline { 2 - 5 } Ibu & telepon & $\boldsymbol{F}$ & $\mathbf{\%}$ & $\boldsymbol{F}$ & $\mathbf{\%}$ \\
& layanan pesan singkat & 9 & 15.9 & 8 & 17.4 \\
& percakapan tatap muka & 28 & 20.5 & 5 & 10.9 \\
\hline Total & & 44 & 100 & 46 & 100 \\
\hline Ayah & telepon & 11 & 25 & 9 & 19.6 \\
& layanan pesan singkat & 11 & 25 & 8 & 17.4 \\
& percakapan tatap muka & 22 & 50 & 29 & 63 \\
\hline Total & 44 & 100 & 46 & 100 \\
\hline
\end{tabular}

Data pada tabel 4 menunjukkan bahwa keberfungsian keluarga pada remaja laki-laki dan perempuan yang menggunakan ICT tidak berbeda secara signifikan $(t=-1.848 ; p=.068)$. Jika dilihat pada aspek keberfungsian keluarga, terdapat dua aspek yang menunjukkan perbedaan signifikan antara remaja laki-laki dan perempuan, yaitu pada aspek respons afektif dan keterlibatan afektif, sedangkan pada lima aspek lainnya tidak ada perbedaan yang signifikan. 
Tabel 4.

Hasil Uji Statistik

\begin{tabular}{lcccccc}
\hline \multicolumn{1}{c}{ Variabel } & \multicolumn{2}{c}{ Laki-laki } & \multicolumn{2}{c}{ Perempuan } & & Sig \\
\hline Keberfungsian keluarga & 129.750 & 16.685 & 136.500 & 17.903 & -1.848 & 0.068 \\
Aspek: & & & & & & \\
Pemecahan masalah & 8.364 & 1.382 & 8.674 & 1.383 & -1.064 & 0.290 \\
Komunikasi & 14.318 & 2.032 & 14.304 & 2.851 & 0.026 & 0.979 \\
Peran & 16.591 & 2.983 & 17.283 & 2.873 & -1.121 & 0.265 \\
Respon afektif & 13.705 & 2.436 & 15.391 & 2.362 & -3.335 & $0.001^{*}$ \\
Keterlibatan afektif & 16.864 & 2.913 & 18.044 & 2.913 & -2.054 & $0.043^{*}$ \\
Kontrol perilaku & 25.682 & 3.489 & 26.935 & 3.422 & -1.720 & 0.089 \\
Fungsi umum keluarga & 34.227 & 5.193 & 35.870 & 5.683 & -1.429 & 0.156 \\
\hline
\end{tabular}

Keterangan: $*<.05$

\section{DISKUSI}

Hasil analisis data menunjukkan tidak terdapat perbedaan keberfungsian keluarga antara remaja laki-laki dan remaja perempuan yang menggunakan ICT. Hasil demikian dapat diartikan bahwa interaksi antara remaja (laki-laki maupun perempuan) dengan orang tuanya terjalin dengan baik. Interaksi di antara anggota keluarga remaja sejauh ini dapat memenuhi kebutuhan mereka, serta pengambilan keputusan dan pencapaian tujuan keluarga lainnya (Lanigan, 2009). Interaksi antara remaja dan orang tua masih lebih banyak terjadi melalui cara tatap muka. Pada sisi lain, intensitas penggunaan ICT oleh remaja juga tergolong tinggi (kategori hampir selalu dan sering) untuk media sosial, pencarian informasi, percakapan, pesan singkat, dan telepon (Sigman, 2010). Interaksi yang baik antara remaja dan orang tua juga dapat mengindikasikan bahwa orang tua cukup intensif dalam memberikan perhatian, dukungan, ataupun pemantauan terhadap anak remaja mereka yang memang masih berada dalam tanggung jawab orang tua (Santrock, 2011).

Hasil penelitian ini menunjukkan bahwa dua dari tujuh aspek keberfungsian keluarga memiliki perbedaan signifikan antara remaja laki-laki dan remaja perempuan, yaitu pada aspek respons afektif dan aspek keterlibatan afektif. Kedua aspek ini berkait dengan afeksi atau masalah emosional. Respons afektif merupakan kemampuan untuk berespons terhadap stimulus yang ada dengan kualitas dan kuantitas perasaan yang tepat. Aspek ini lebih melihat pada kapasitas anggota keluarga untuk merasakan dan mengekspresikan emosi mereka secara tepat. Dalam hal ini remaja perempuan $\left(M_{\text {respons afektif perempuan }}=15.391\right)$ lebih dapat mengekspresikan dan menerima respons emosi yang ada dalam keluarga dibanding remaja laki-laki $\left(\mathbf{M}_{\text {respons afektif laki-laki }}=13.705\right)$. Hasil 
penelitian Rime dan Zech (dalam Retnowati, Widhiarso, \& Rohmani, 2003) menunjukkan bahwa kepedulian dan penerimaan orang tua berpengaruh terhadap pengungkapan emosi anak, karena orang tua merupakan sasaran awal pengungkapan emosi pada masa anak-anak. Hasil penelitian Retnowati dkk., (2003) juga menunjukkan bahwa reaksi orang tua terhadap pengungkapan emosi anak akan terbawa pada pengungkapan emosi anak ketika menginjak masa dewasa. Sebaliknya, tidak adanya perhatian orang tua pada anak bahkan perlakuan kasar orang tua kepada anak juga berpengaruh pada bentuk ekspresi emosi anak.

Aspek keterlibatan afektif melihat bagaimana setiap anggota keluarga dapat menunjukkan ketertarikan dan penghargaan terhadap aktivitas dan minat anggota keluarga lainnya. Dalam hal ini remaja perempuan $\left(M_{\text {keterlibatan afektif perempuan }}=18.044\right)$ lebih dapat menunjukkan dan memberikan tanggapan dan penghargaan terhadap kegiatan yang dilakukan oleh anggota keluarganya dibandingkan dengan remaja laki-laki (Mketerlibatan afektif perempuan $=16.864)$. Secara umum, remaja perempuan lebih mudah melibatkan emosi daripada kognisi dalam menghadapi dan menanggapi suatu kondisi, sebaliknya remaja laki-laki cenderung lebih banyak menggunakan nalarnya daripada emosinya dalam menghadapi dan menanggapi suatu situasi. Kemampuan remaja perempuan dalam menunjukkan respons afektif dan keterlibatan afektif lebih tinggi daripada remaja laki-laki. Hal ini sesuai dengan karakteristik remaja perempuan yang cenderung lebih mudah terstimulasi secara afektif dibanding remaja laki-laki (Santrock, 2011).

Hasil analisis untuk lima aspek lainnya (pemecahan masalah, komunikasi, peran, kontrol perilaku, dan fungsi umum keluarga) tidak menunjukkan adanya perbedaan yang signifikan antara remaja laki-laki dan remaja perempuan. Pada aspek komunikasi, rata-rata nilai laki-laki hampir sama dengan rata-rata nilai perempuan. Hal ini dapat diartikan bahwa remaja laki-laki dan remaja perempuan sama-sama mempunyai intensitas pertukaran informasi secara verbal yang cukup dengan orang tuanya. Sarana komunikasi remaja dengan orang tua juga bervariasi, yaitu menggunakan telepon, pesan singkat/percakapan, dan tatap muka. Hasil menunjukkan bahwa remaja paling banyak berkomunikasi secara tatap muka dengan orang tuanya. Komunikasi tatap muka remaja dengan ibu lebih tinggi dibandingkan dengan ayah, yakni sebanyak 63.6 persen remaja laki-laki berkomunikasi tatap muka dengan ibu dibandingkan dengan ayah (50\%). Banyaknya remaja perempuan yang berkomunikasi tatap muka dengan ibu adalah 71.7 persen sedangkan dengan ayah sebanyak 63 persen.

Pada empat aspek lainnya nilai remaja perempuan lebih besar daripada remaja laki-laki. Kondisi demikian dapat menggambarkan bahwa orang tua mempunyai kontribusi yang lebih tinggi pada remaja perempuan daripada remaja laki-laki, dalam hal pemecahan masalah, peran, kontrol 
perilaku, dan fungsi keluarga secara umum. Hal ini juga dapat dikaitkan dengan faktor budaya bahwa perhatian dan pemantauan orang tua cenderung lebih ketat pada anak perempuan dibandingkan pada anak laki-laki.

Secara deskriptif, data penelitian ini menunjukkan bahwa perangkat ICT yang sering digunakan remaja laki-laki adalah telepon, pesan singkat, percakapan, pencarian informasi, dan media sosial. Surat elektronik dan layanan percakapan video jarang digunakan oleh remaja laki-laki. Apabila diperhatikan, intensitas penggunaan ICT pada remaja laki-laki pada kategori sering dan jarang. Jumlah partisipan laki-laki yang termasuk kategori jarang dan sering menggunakan ICT untuk pencarian informasi sama banyak (29.5\%).

Ada dua jenis ICT yang hampir selalu digunakan oleh majoritas remaja perempuan, yaitu percakapan dan media sosial. Intensitas remaja perempuan dalam penggunaan ICT lebih tinggi (kategori hampir selalu) dibandingkan remaja laki-laki (kategori sering), sedangkan pencarian informasi sering digunakan oleh majoritas remaja baik laki-laki maupun perempuan. Perangkat ICT lainnya, yaitu telepon, layanan pesan singkat, dan layanan percakapan video hanya digunakan kadang-kadang saja.

Penelitian ini memiliki dua kekurangan utama, yakni pada sampel dan jenis perangkat ICT. Keterwakilan sampel penelitian masih tergolong lemah, mengingat pengambilan sampel bersifat insidental. Jenis pemilihan perangkat ICT penelitian ini terbatas pada telepon genggam, sementara terdapat kemungkinan partisipan juga menggunakan perangkat ICT lain.

\section{SIMPULAN DAN SARAN}

\section{Simpulan}

Berdasarkan hasil penelitian ini, maka peneliti menyimpulkan bahwa keberfungsian keluarga pada remaja yang menggunakan ICT sama baiknya, baik laki-laki maupun perempuan. Secara umum hasil penelitian ini menunjukkan bahwa keberfungsian remaja perempuan dan lakilaki yang menggunakan ICT, khususnya dalam hal respons afektif dan keterlibatan afektif berbeda secara signifikan. Pada kedua aspek tersebut nilai remaja perempuan lebih tinggi dibanding remaja laki-laki. Remaja perempuan lebih sensitif secara emosional daripada remaja laki-laki.

Pada penggunaan perangkat ICT, partisipan laki-laki lebih sering menggunakan telepon, layanan pesan singkat, percakapan, pencarian informasi, dan media sosial. Partisipan perempuan 
lebih sering menggunakan layanan percakapan dan media sosial. Surat elektronik dan percakapan melalui video jarang digunakan oleh partisipan laki-laki maupun perempuan.

\section{Saran Teoretis}

Studi ini masih bersifat sederhana, namun dapat menjadi salah satu acuan guna penelitian lebih luas terkait keberfungsian keluarga dan pemanfaatan perangkat ICT pada remaja. Peneliti menyarankan penelitian lebih lanjut dengan memperluas jenis perangkat ICT dan pemilihan sampel yang lebih fokus. Penelitian terkait pola maupun kualitas hubungan antara remaja dan orang tua dalam konteks perkembangan perangkat ICT juga menarik untuk diteliti. Hal ini dikarenakan fenomena perkembangan teknologi yang semakin erat penggunaannya dalam kehidupan sehari-hari.

\section{Saran Praktis}

Saran praktis bagi para orang tua, baik ayah maupun ibu diharapkan dapat lebih memaksimalkan interaksi tatap muka dengan anak remaja mereka, baik laki-laki maupun perempuan. Tujuannya untuk memberikan pendampingan dalam memecahkan masalah, meningkatkan komunikasi, dan merupakan bentuk kontrol terhadap anaknya. Orang tua juga dapat menggunakan perangkat ICT untuk meningkatkan keberfungsian keluarga dengan anak usia remaja, baik laki-laki maupun perempuan. Saran bagi remaja, baik laki-laki maupun perempuan diharapkan dapat menggunakan perangkat ICT untuk mendukung keberfungsian keluarga. Caranya dengan memberikan informasi secara tepat mengenai aktivitas mereka kepada orang tua atau menanggapi secara baik informasi yang ingin diketahui oleh orang tua.

\section{REFERENSI}

Aziz, A. (2016). Handphone mempengaruhi terhadap perilaku remaja usia SLTP (13-15 tahun) di dusun Tegalpare kecamatan Muncar kabupaten Banyuwangi. Darussalam: Jurnal Pendidikan, Komunikasi dan Pemikiran Hukum Islam, 8(2), 123-148.

Bonnaire, C., \& Phan, O. (2017). Relationships between parental attitudes, family functioning and internet gaming disorder in adolescents attending school. Psychiatry Research, 255, 104-110.

Carvalho, J., Francisco, R., \& Relvas, A. P. (2015). Family functioning and information and communication technologies: How do they relate? A literature review. Computers in Human Behavior, 45, 99-108. 
Chandra, H. D. (2017). Studi deskriptif keberfungsian keluarga pada remaja usia SMP pengguna teknologi informasi dan komunikasi. (Skripsi tidak dipublikasikan). Universitas Surabaya, Indonesia.

Djabumir, N. (2015). Hubungan antara family functioning dan psychological wellbeing pada emerging adulthood. (Skripsi tidak dipublikasikan). Universitas Surabaya, Indonesia.

Devitt, K., \& Roker, D. (2009). The role of mobile phones in family communication. Children \& society, 23(3), 189-202.

Epstein, N. B., Baldwin, L. M., \& Bishop, D. S. (1983). The McMaster family assessment device. Journal of Marital and Family Therapy, 9(2), 171-180.

Lanigan, J. D. (2009). A sociotechnological model for family research and intervention: How information and communication technologies affect family life. Marriage family \& Family Review, 45(6-8), 587-609.

Retnowati, S., Widhiarso, W., \& Rohmani, K. W. (2003). Peranan keberfungsian keluarga pada pemahaman dan pengungkapan emosi. Jurnal Psikologi, 2, 91-104.

Romero-Ruiz, K., Echeverri-Sanchez, L., Pena-Plata, J.,Vasquez-Giraldo, S., Aguilera-Cardona, M., Herazo-Avendano, C., Valencia-Arias, A., \& Bran-Piedrahita, L. (2017). Information and communication technologies impact on family relationship. Procedia-Social and Behavioral Sciences, 237, 30-37.

Santrock, J. W. (2011). Life-span development (13th ed.). New York, NY: McGraw-Hill.

Sigman, A. (2010). The impact of screen media on children: A eurovision for parliament. Ditemu kembali dari https://www.steinereducation.edu.au/wp-content/uploads/uk_screen_time.pdf 